\title{
Growth and yield of Radish cultivars as influenced by phosphorus levels
}

Roshan Zeb ${ }^{1}$, Gohar Ayub ${ }^{1}$, Mohammad Ilyas ${ }^{1 *}$, Manzoor Ahmad ${ }^{2}$, Luqman $^{3}$, Gulzar Ullah ${ }^{1}$, Ammara Saeed ${ }^{1}$ and Qurat ul Ain ${ }^{1}$

1. Department of Horticulture, The University of Agriculture Peshawar-Pakistan

2. Department of Agriculture Bacha Khan University Charsadda, Pakistan

3. Department of Weed Science, The University of Agriculture Peshawar-Pakistan

*Corresponding author's email: Ilyas_swati88@yahoo.com

Citation

Roshan Zeb, Gohar Ayub, Mohammad Ilyas, Manzoor Ahmad, Luqman, Gulzar Ullah, Ammara Saeed and Qurat ul Ain. Growth and yield of Radish cultivars as influenced by phosphorus levels.. Pure and Applied Biology. Vol. 5, Issue 2, 2016, pp213-222. http://dx.doi.org/10.19045/bspab.2016.50028

\begin{tabular}{llll}
\hline \hline Received: 16/12/2015 & Revised: 09/0/2016 & Accepted: 17/02/2016 & Online First: 19/02/2016 \\
\hline
\end{tabular}

\section{Abstract}

A field trial was conducted at Ornamental Horticulture nursery, Department of Horticulture, University of Agriculture, Peshawar in winter 2014 to determine the response of phosphorus levels on growth and yield components of Radish Cultivars,. Randomized Complete Block Design (RCBD) with split plot arrangement was used and there were three replication. Phosphorus levels were allotted to main plot, while cultivars (Nong woo bio, Long red radish, Mino early long white and Green neck) were assigned to sub plots. Results showed that all the growth parameters were statistically different among cultivars as well as phosphorus levels. Green neck cultivar showed maximum root diameter $(3.27 \mathrm{~cm})$, root weight $(232.03 \mathrm{~g})$, yield per plot $(1.79 \mathrm{~kg})$, and total yield $\left(29.88\right.$ tons ha- $\left.{ }^{-1}\right)$, while Long red radish cultivar showed minimum results in root diameter $(1.54 \mathrm{~cm})$, root weight $(125.11 \mathrm{~g})$, yield per plot $(0.69 \mathrm{~kg})$ and total yield (21.30 tons $\left.\mathrm{ha}^{-1}\right)$. Regarding phosphorus levels, no of leaves (20.27), fresh leaf weight (116.38 $\mathrm{g}$ ), root length $(26.29 \mathrm{~cm})$ maximum root weight $(255.39 \mathrm{~g})$, root diameter $(3.03 \mathrm{~cm})$, yield per plot $(3.63 \mathrm{~kg})$ and total yield $\left(29.40\right.$ tons $\left.\mathrm{ha}^{-1}\right)$ were recorded at phosphorus level $60 \mathrm{~kg} \mathrm{ha}^{-1}$ while minimum no of leaves $(16.33)$, fresh leaf weight $(98.13 \mathrm{~g})$, root length $(20.77 \mathrm{~cm})$ root weight $(154.41 \mathrm{~g})$, root diameter $(2.27 \mathrm{~cm})$, yield per plot $(2.64 \mathrm{~kg})$ and total yield $\left(23.25 \mathrm{tons}^{-1}\right)$ were recorded in control treatment. Maximum Cultivar Green neck supplied with $60 \mathrm{~kg} \mathrm{ha}^{-1}$ of P showed better results and hence recommended for radish growers in Peshawar Valley.

Key words: Radish (Raphanus sativus L.); Phosphorous Levels; Cultivars; Growth and Yield Components

\section{Introduction}

Radish (Raphanus sativus L.) belongs to the family Brassicaceae. Radish is related to mustard and cabbage, however belongs to changed genus. The Caspian Sea and Eastern Mediterranean region is most likely the original gene Centre for this species. In ancient times, radish was grown in the
Mediterranean region and spread to China in $500 \mathrm{BC}$ and to Japan in 700 AD. For kitchen gardening, it is a favorite crop, as it is easy to grow and is ready for use in three to six weeks after sowing. In both tropical and temperate regions it is a famous root vegetable. Radish is grown for its tender 
young tuberous root which is utilized either cooked or raw [1].

It has cooling effect, prevents constipation, increases appetite and its roots and leaves are very tasty when cooked together. It is recommended to the patients suffering from piles, liver trouble, enlarged spleen and jaundice [2]. On commercial scale, its leaves are used for extraction of protein and its seeds are potential source of non-drying fatty oil appropriate for soap formation, illuminating and edible purposes. Radish leaves are also used for cooking purposes and are rich source of vitamin A and C and different minerals [3]. Radishes are heat tolerant, but in order to develop flavor, texture and size, a cool period having temperatures from $10-15^{\circ} \mathrm{C}$ is essential even though varieties differ in temperature sensitivity. It must be sown rapidly for getting soft, tender and attractive radishes. They are both a spring as well as fall crop [4]. Radish production worldwide is assessed as seven million tons annually, which is $2 \%$ of the total production of vegetables in world. Average yield of radish is 18.67 tons in Pakistan with a total production of 113,163 tons. Radish is grown on an area of 6061 hectares in our country. Sheikhupura, Rahim Yar Khan, Sahiwal, Toba Taik Singh and Okara are major known districts for production of radish.

The growth and yield of radish mainly depends on soil conditions and climate. It is always a combination of various characters which make a particular cultivar suitable for commercial purpose. Various varieties require different soil types and climatic conditions for their optimum performance. Therefore, for specific regions different varieties have to be identified. Certain morphological characters go along with the production potentialities of the cultivars. Optimum fertilization through organic, inorganic and bio fertilizers are necessary for production of good quality radish.
Appropriate fertilizers ensure rapid, crisp and mild radishes but excess is not good. Phosphorus has significant role in production of energy rich compounds like AMP, ADP and ATP which are required for photosynthesis and respiration. It is a fundamental element of nucleic acids and phospholipids and a few co enzymes. It plays vital role in transferring energy with in plant cells, cell division, and formation of meristem tissue; promote root growth, flowering and development of seed and fruit. Deficiency of phosphorus leads to reddish or purple leaves, stems and branches, stunted top growth that results in low yield and ultimately poor quality of crops [5].

\section{Materials and methods}

An experiment entitled "Growth and yield of radish cultivars as influenced by phosphorus levels" was performed at Ornamental Nursery, The University of Agriculture, Peshawar in winter 2014. Soil was ploughed up thoroughly and it was leveled using cutter. At proper height, ridges were formed manually. Irrigation was done after completion of sowing. Row to row distance was $30 \mathrm{~cm}$, while plant to plant distance was kept $10 \mathrm{~cm}$. Weeding and irrigation was done regularly. Before application of fertilizer, soil was analyzed for various nutrients. Soil samples were collected up to depth of $0-20 \mathrm{~cm}$ which were taken randomly from the plot and analyzed in Soil Science Laboratory of Agriculture University Peshawar. The experiment was laid out according to randomized complete block design (RCBD) with split plot arrangement. Two factors i.e. phosphorus levels and cultivars of radish are involved in experiment. Phosphorus levels $(0,40,60$ and $80 \mathrm{~kg} \mathrm{ha}^{-1}$ ) were kept in main plots and cultivars (Nong woo Bio, Long red radish, Mino early long white and Green neck) were in sub plots. A total of sixteen treatments were replicated thrice. Nitrogen and 
potassium was applied as basic dose. The source of phosphorus in experiment was Single Super Phosphate that contains 20\% of phosphorus. Nitrogen source was urea that contains $46 \% \mathrm{~N}$ and source of potassium was $\mathrm{K}_{2} \mathrm{SO}_{4}$ having $50 \% \mathrm{~K}$. During the course of experimentation data was recorded on number of Leaves plant $^{-1}$, fresh leaf weight $(\mathrm{g})$, root length $(\mathrm{cm})$, root diameter $(\mathrm{cm})$, root weight $(\mathrm{g})$, yield per plot $(\mathrm{kg})$ and total yield (tons $\mathrm{ha}^{-1}$ ). The data on different parameters and was subjected to Analysis of Variance (ANOVA) technique to reveal the difference among various treatments and their interaction. In situations when differences were found significant, then their means were compared for differences using Least Significant Difference (LSD) test at $5 \%$ level of probability. For computing the ANOVA and LSD, Statistical computer software, MSTATC (Michigan State University, USA), was used.

\section{Results and discussion}

\section{Number of leaves plant ${ }^{-1}$}

It is cleared from the statistical analysis of data that different phosphorus levels and cultivars significantly influenced number of leaves of radish (Figure 1) whereas their interaction was found non-significant (Table
(20.27) were noted in plants treated with phosphorus at level of $60 \mathrm{~kg} \mathrm{ha}^{-1}$, while minimum number of leaves plant ${ }^{-1}$ (16.33) were recorded in control treatment. There was a significant variation observed in different radish cultivars, Green neck showed maximum number of leaves (20.72) while the minimum number of leaves (12.34) were found in Long red radish. The varietal differences among various radish cultivars might be due to the genetic makeup of the cultivars under trial. For growth and development of plant, $\mathrm{P}$ is an important nutrient. It plays an ultimate role in metabolism and energy producing associations in plants that ultimately lead to the development of more number of leaves. The combination of $70 \mathrm{~kg}$ per ha $\mathrm{N}, 90 \mathrm{~kg}$ per ha $\mathrm{P}_{2} \mathrm{O}_{5}$ and control $\mathrm{K}_{2} \mathrm{O}$ showed best results. Alike results were obtained by [6], [7] and [8]. Deficiency of Phosphorus limits the production of plant because the mobility of Phosphorus is low in soil and the root system. To explore its mobility in plant and its role in plant top development, 10 and 20 $\mathrm{mg} / \mathrm{l}$ phosphorus in radish was applied. Fresh and dry matter increased with phosphorus application [9].

1). Highest number of leaves per plant

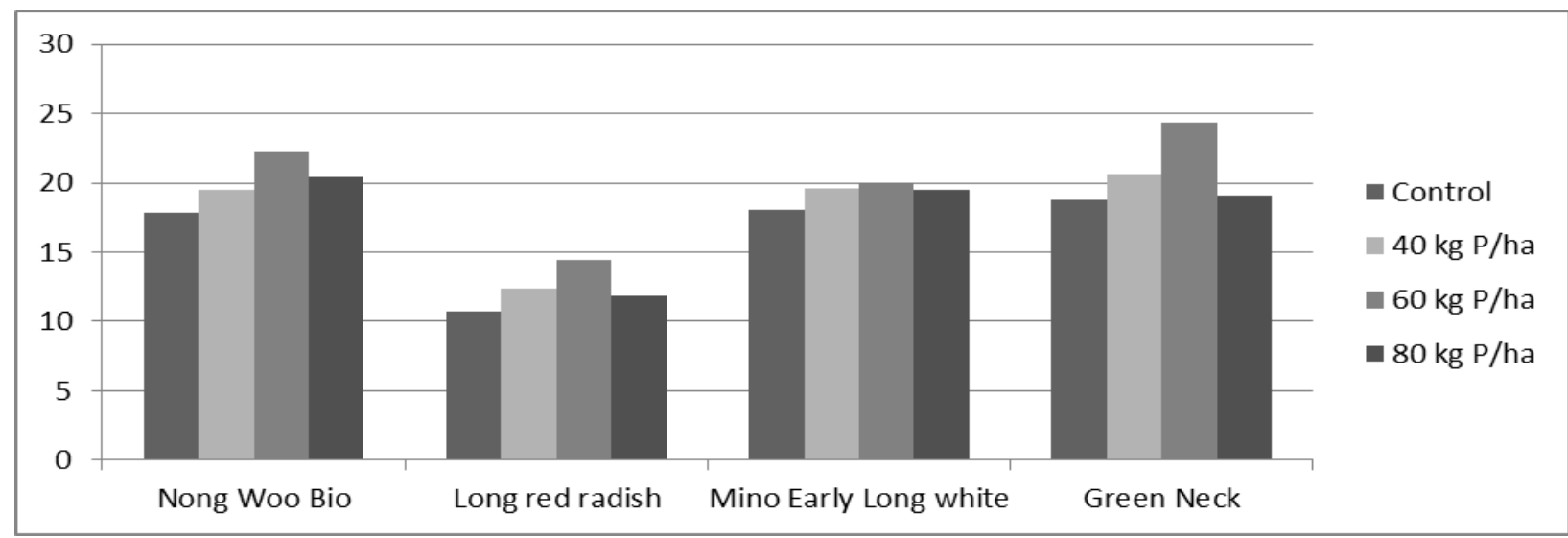

Figure 1. Interaction between radish cultivars and phosphorus levels affected number of leaves plant $^{-1}$ 
Table 1. Growth and yield attributes of radish cultivars as influenced by different levels of Phosphorous

\begin{tabular}{|c|c|c|c|c|c|c|c|}
\hline $\begin{array}{l}\text { Treatme } \\
\text { nts }\end{array}$ & $\begin{array}{l}\text { No of } \\
\text { leaves } \\
\text { Plant }^{-1}\end{array}$ & $\begin{array}{l}\text { Fresh leaf } \\
\text { weight(g) }\end{array}$ & $\begin{array}{l}\text { Root } \\
\text { length } \\
\text { (cm) }\end{array}$ & $\begin{array}{l}\text { Root } \\
\text { diamete } \\
\text { r }(\mathbf{c m})\end{array}$ & $\begin{array}{l}\text { Root } \\
\text { weight (g) }\end{array}$ & $\begin{array}{l}\text { Yield } \\
\text { plot }^{-1}(\mathrm{Kg})\end{array}$ & $\begin{array}{l}\text { Total } \\
\text { yield t } \\
\text { ha }^{-1}\end{array}$ \\
\hline \multicolumn{8}{|c|}{ Phosphorous Levels } \\
\hline $\mathrm{P} 1=$ & $16.33 c$ & $98.13 \mathrm{c}$ & $20.77 \mathrm{c}$ & $2.27 \mathrm{c}$ & $154.41 d$ & $2.64 b$ & $23.25 \mathrm{c}$ \\
\hline $\mathrm{P} 2=$ & $18.01 \mathrm{~b}$ & $108.19 b$ & $23.54 \mathrm{~b}$ & $2.70 \mathrm{~b}$ & $209.80 \mathrm{~b}$ & $3.12 b$ & $26.96 \mathrm{~b}$ \\
\hline $\mathrm{P} 3=$ & $20.27 \mathrm{a}$ & $116.38 \mathrm{a}$ & $26.29 a$ & $3.03 \mathrm{a}$ & $255.39 a$ & $3.63 a$ & $29.40 \mathrm{a}$ \\
\hline $\mathrm{P} 4$ & $17.72 \mathrm{~b}$ & $104.99 b c$ & $23.12 b$ & $2.66 \mathrm{~b}$ & $186.85 \mathrm{c}$ & $2.96 \mathrm{~b}$ & $26.15 b$ \\
\hline LSD & 0.907 & 8.035 & 1.511 & 0.157 & 17.332 & 0.488 & 2.090 \\
\hline \multicolumn{8}{|l|}{ Cultivars } \\
\hline Cv1 & 20.00ab & $118.40 \mathrm{a}$ & $26.39 \mathrm{ab}$ & $3.11 \mathrm{~b}$ & $227.40 \mathrm{a}$ & $3.28 \mathrm{ab}$ & $27.43 \mathrm{ab}$ \\
\hline $\mathrm{Cv} 2$ & $12.34 \mathrm{c}$ & $73.56 \mathrm{~b}$ & $14.50 \mathrm{c}$ & $1.54 \mathrm{~d}$ & $125.11 \mathrm{~b}$ & $2.39 \mathrm{c}$ & $21.30 \mathrm{c}$ \\
\hline Cv3 & $19.28 b$ & $115.16 \mathrm{a}$ & $2.45 b$ & $2.75 \mathrm{c}$ & $221.91 \mathrm{a}$ & $3.19 \mathrm{~b}$ & $27.15 b$ \\
\hline $\mathrm{Cv} 4$ & $20.72 \mathrm{a}$ & $120.57 \mathrm{a}$ & $27.38 \mathrm{a}$ & $3.27 \mathrm{a}$ & $232.03 \mathrm{a}$ & $3.49 \mathrm{a}$ & $29.88 \mathrm{a}$ \\
\hline LSD & 1.264 & 6.351 & 1.824 & 0.154 & 12.143 & 0.252 & 2.420 \\
\hline \multicolumn{8}{|c|}{ Interactions } \\
\hline $\mathrm{P} 1 \times \mathrm{Cv} 1$ & 17.88 & 110.33 & 23.07 & 2.66 & 156.67 & 2.67 & 21.77 \\
\hline $\mathrm{P} 1 \times \mathrm{Cv} 2$ & 10.67 & 69.37 & 13.59 & 1.33 & 98.33 & 2.05 & 18.92 \\
\hline $\mathrm{P} 1 \times \mathrm{Cv} 3$ & 18.00 & 106.63 & 22.39 & 2.47 & 177.24 & 2.87 & 24.55 \\
\hline $\mathrm{P} 1 \times \mathrm{Cv} 4$ & 18.78 & 106.19 & 24.03 & 2.63 & 185.41 & 2.96 & 27.75 \\
\hline $\mathrm{P} 2 \times \mathrm{Cv} 1$ & 19.44 & 118.74 & 28.08 & 3.10 & 249.67 & 3.27 & 28.56 \\
\hline $\mathrm{P} 2 \times \mathrm{Cv} 2$ & 12.37 & 74.03 & 12.13 & 1.62 & 128.23 & 2.38 & 21.67 \\
\hline $\mathrm{P} 2 \times \mathrm{Cv} 3$ & 19.61 & 116.86 & 25.89 & 2.88 & 224.58 & 3.34 & 27.67 \\
\hline $\mathrm{P} 2 \times \mathrm{Cv} 4$ & 20.61 & 123.14 & 28.04 & 3.21 & 236.70 & 3.47 & 29.93 \\
\hline $\mathrm{P} 3 \times \mathrm{Cv} 1$ & 22.23 & 129.30 & 29.00 & 3.37 & 283.27 & 3.87 & 30.31 \\
\hline $\mathrm{P} 3 \times \mathrm{Cv} 2$ & 14.44 & 77.87 & 17.33 & 1.73 & 153.63 & 2.84 & 24.43 \\
\hline $\mathrm{P} 3 \times \mathrm{Cv} 3$ & 20.05 & 123.54 & 28.18 & 2.92 & 285.66 & 3.43 & 29.45 \\
\hline $\mathrm{P} 3 \times \mathrm{Cv} 4$ & 24.36 & 134.82 & 30.65 & 4.10 & 299.00 & 4.37 & 33.42 \\
\hline $\mathrm{P} 4 \times \mathrm{Cv} 1$ & 20.45 & 115.24 & 25.40 & 3.33 & 220.00 & 3.30 & 29.08 \\
\hline $\mathrm{P} 4 \times \mathrm{Cv} 2$ & 11.89 & 72.97 & 14.94 & 1.45 & 120.23 & 2.30 & 20.20 \\
\hline $\mathrm{P} 4 \times \mathrm{Cv} 3$ & 19.44 & 113.60 & 25.34 & 2.73 & 200.17 & 3.10 & 26.90 \\
\hline $\mathrm{P} 4 \times \mathrm{Cv} 4$ & 19.11 & 118.13 & 26.80 & 3.14 & 207.00 & 3.15 & 28.42 \\
\hline LSD & $\mathrm{NS}$ & NS & $\mathrm{NS}$ & 0.309 & 24.287 & NS & $\mathrm{NS}$ \\
\hline
\end{tabular}

Means followed by different letter (s) within each category are significantly different using LSD test at $\mathrm{P} \leq 0.05$. NS $=$ Non-significant

\section{Fresh leaf weight $(\mathrm{g})$}

The statistical analysis of data revealed that different phosphorus levels and cultivars significantly influenced fresh leaf weight of radish whereas their interaction (Figure 2) was found non-significant. The mean Table shows that highest fresh leaf weight
$(116.38 \mathrm{~g})$ was noted in plants treated with phosphorus at rate of $60 \mathrm{~kg}$ per ha, whereas minimum fresh leaf weight (98.13 g) was recorded in plants treated with phosphorus in control treatment. There was a significant variation observed in different radish in which cultivar Green neck showed 
maximum fresh leaf weight $(120.57 \mathrm{~g})$ while the minimum number of leaves $(73.56 \mathrm{~g})$ was observed in Long red radish.The reason may be due to noticeable differences among various cultivars of radish. Supreme translocation of photo integrates in the existence of ideal temperature during the vegetative growth period that resulted in the assembling of more number of leaves and ultimately contributes to the leaf fresh weight. Macronutrients such as nitrogen and phosphorous plays an important role in the growth and development process of the plant which encourages vegetative growth [2] and [10], and phosphorus encourages root development and also providing energy by forming ATP [11]. Increasing phosphorous significantly increased the vegetative and yield attributes of radish [12].

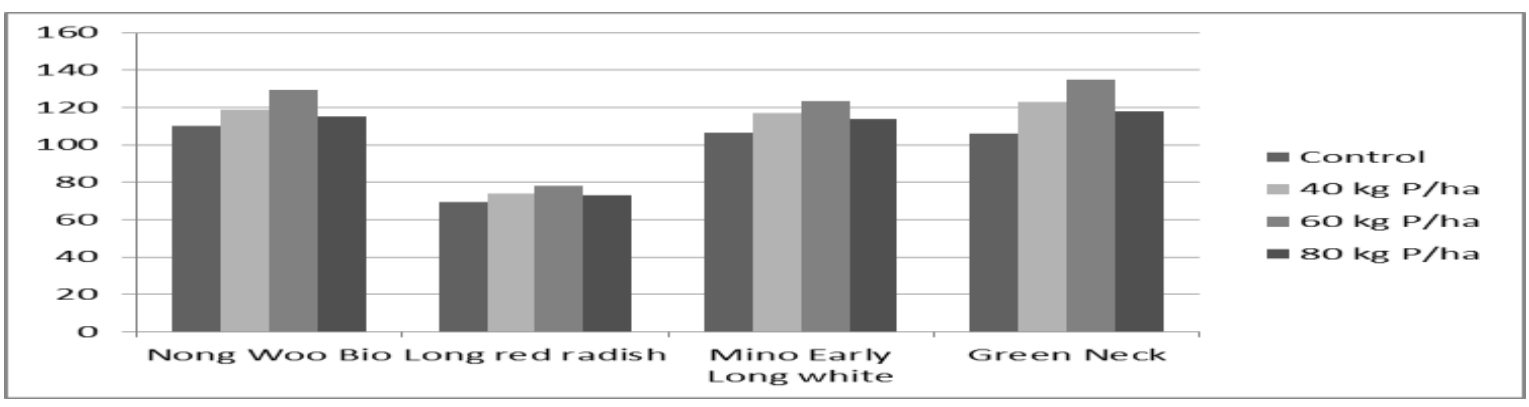

Figure 2. Interaction between radish cultivars and phosphorus levels affected fresh leaf weight (g)

Root length $(\mathbf{c m})$

It is evident from the statistical analysis of data that different phosphorus levels and cultivars significantly influenced root length (cm) of radish whereas their interaction (Figure 3) was found non-significant. From the mean Table it is clear that maximum root length $(26.29 \mathrm{~cm})$ was recorded in plants treated with phosphorus at rate of $60 \mathrm{~kg}$ per ha, whereas minimum root length $(20.77 \mathrm{~cm})$ was noted in control treatment. Among cultivars, Green neck showed maximum root length $(27.38 \mathrm{~cm})$ while the minimum root length $(14.50 \mathrm{~cm})$ was observed in Long red radish. This might be due to marked differences among the radish cultivars or it might be due to the increased activity of source sink which translocate the essential nutrients from the leaves and ultimately increased the root weight, number and also the root length of radish. The results are in relation with the results of [13], who evaluated radish cultivars and found that radish cultivar Japanese White gave maximum yield, longest roots and more number of leaves. Root length was improved when phosphorus and potash at rate of 100 $\mathrm{kg}$ per ha was practiced on different radish cultivars along with nitrogen [14].

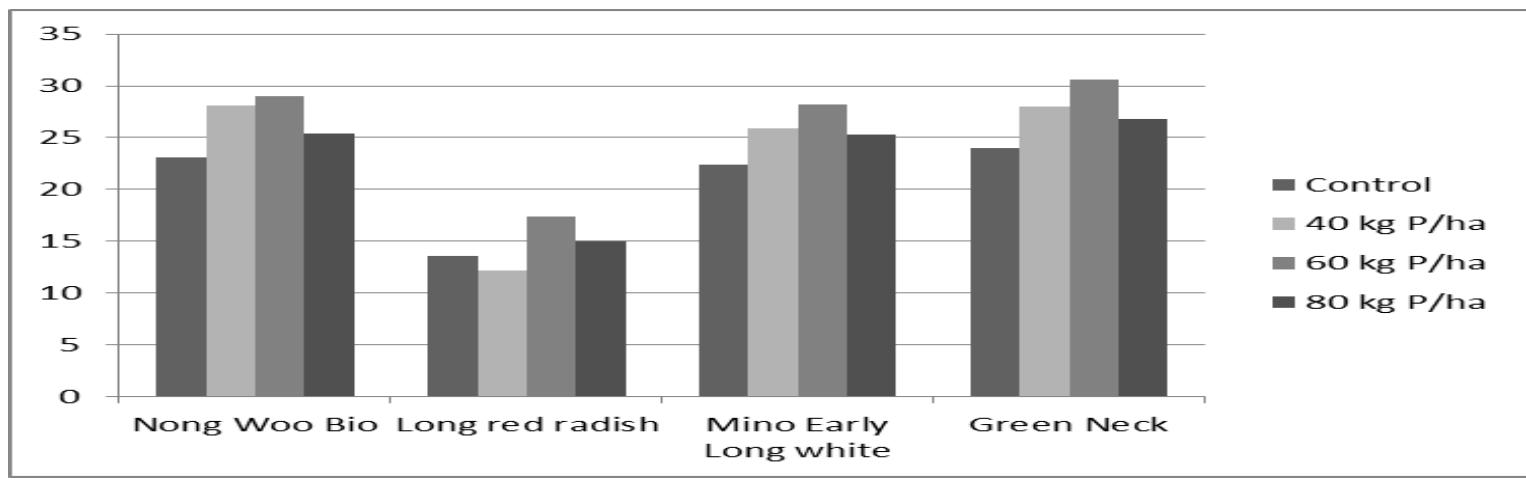

Figure 3. Interaction between radish cultivars and phosphorus levels affected root length (cm) 


\section{Root diameter (cm)}

The statistical analysis of data showed that different phosphorus levels and cultivars significantly influenced root diameter $(\mathrm{cm})$ of radish whereas their interaction (Figure 4) was found non-significant. From the mean Table it is clear that extreme root diameter $(3.03 \mathrm{~cm})$ were recorded in plants treated with phosphorus at rate of $60 \mathrm{~kg}$ per ha while minimum root diameter $(2.27 \mathrm{~cm})$ were noted in control treatment. There was a significant variation observed in different radish cultivars, in which cultivar Green neck showed maximum root length (3.27 $\mathrm{cm})$ while the minimum root length $(1.54$ $\mathrm{cm})$ was observed in Long red radish. The environment plays a very vital role in the differences among the cultivars under trail. Better results shown by cultivar might be the reason that, the cultivar best suited the climatic condition of Peshawar which showed better results while the other cultivars don't respond to the climatic conditions of Peshawar. Root diameter related with the increase and decrease in phosphorous levels. Maximum root diameter may be due to increased uptake of nitrogen and potash as phosphorous helps in uptake of nutrients. This may result in increased content of chlorophyll in leaves that leads to enhanced production of carbohydrates and accumulation of further new cells [15]. Many investigators stated that phosphorus source is urgently needed to enhance plant vegetative growth in radish. [16] also reveals the same result. He observed that dry shoot mass, leaf area and root shoot mass ratio were increased when phosphorus was applied with nitrogen. Phosphorus increased diameter, height, and leaf area of celery. Nitrogen interacted with phosphorus and affected all growth variables in a better way. Significant effect was observed for all growth parameters by the interaction of phosphorus and nitrogen in an optimum amount. Application of $\mathrm{N}, \mathrm{P}$ and $\mathrm{K}$ increased head weight over the controlled treatments. The effect of different doses of NPK on cabbage were studied by [17] and [18] revealed that curd diameter was more effected by increased NPK levels.

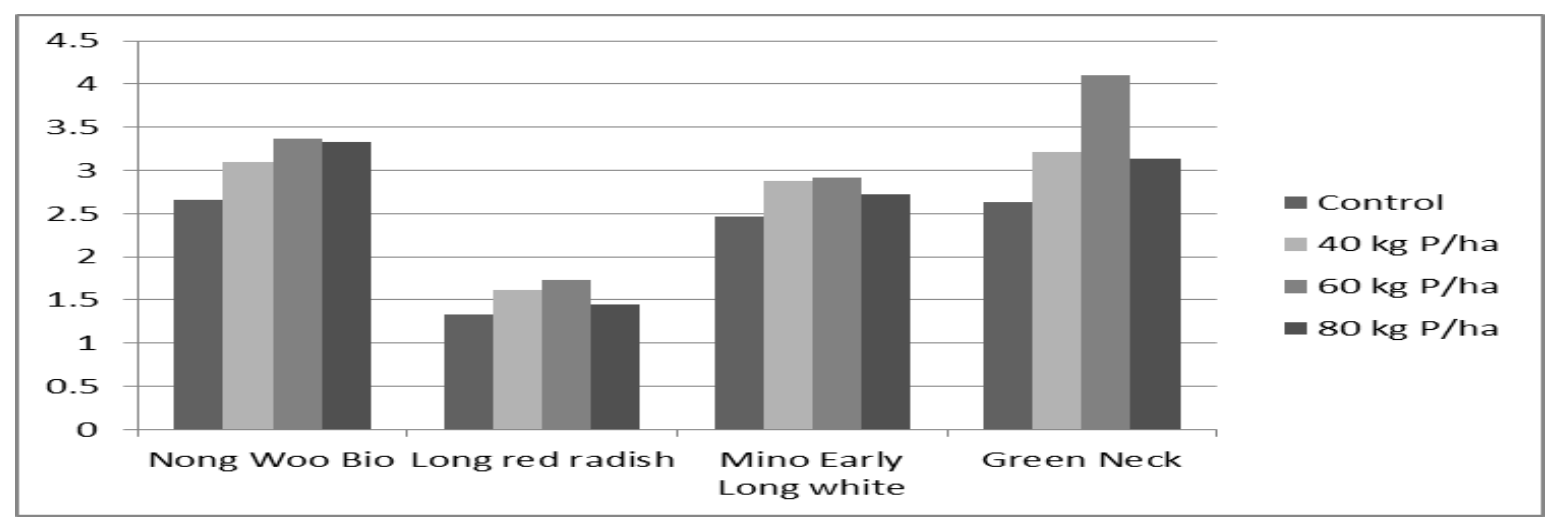

Figure 4. Interaction between radish cultivars and phosphorus levels affected root diameter (cm)

\section{Root weight ( $g$ )}

The statistical analysis of data revealed that different phosphorus levels and cultivars significantly influenced fresh root weight $(\mathrm{g})$ of radish whereas their interaction (Figure 5) was found non-significant. From the mean Table it is cleared that maximum fresh root weight (180.12 g) were recorded in plants treated with $80 \mathrm{~kg} \mathrm{P} \mathrm{ha-1}$, while minimum fresh root weight $(65.12 \mathrm{~g})$ were recorded in untreated plants with phosphorus. There was a significant variation observed in different radish in which cultivar Green neck showed 
maximum fresh root weight $(178.99 \mathrm{~g})$ while the minimum fresh root weight $(94.44$ g) was observed in Nong woo bio.A significant variation was observed in different radish cultivars. This might be due to the genetic makeup of cultivars under trail. Similarly phosphorous is a constituent of vital molecules like nucleic acids, phospholipids and ATPs. It is involved in numerous functions of plants, comprising controlling enzyme reactions, regulation of metabolic pathways, energy transfer, photosynthesis and transformation of carbohydrates as well as formation of oils. Application of $90 \mathrm{~kg} \mathrm{~N}$ and $30 \mathrm{~kg} \mathrm{P}_{2} \mathrm{O}_{5}$ produced the highest root yield per ha on radish cultivar Japanese white during the rabbi season [19]. Root yield and growth components were significantly influenced by NP combinations and increased levels of nitrogen and $\mathrm{P}_{2} \mathrm{O}_{5}$ fertilizer combination showed significantly increased growth and yield traits [20].

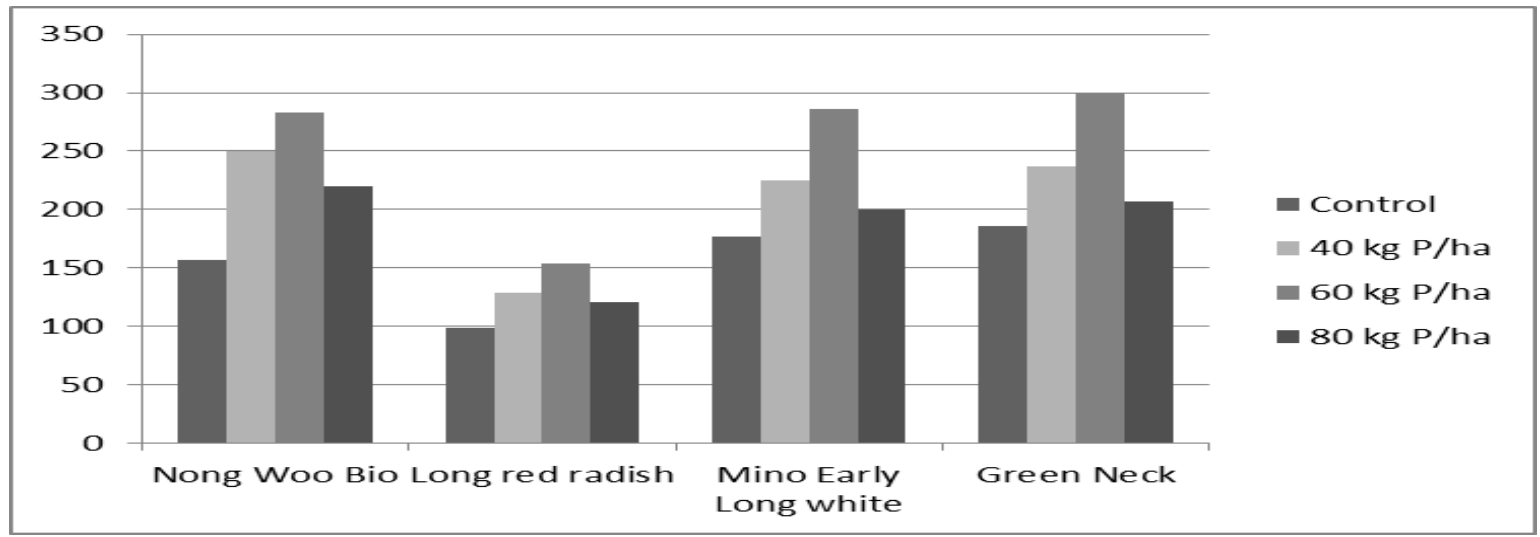

Figure 5. Interaction between radish cultivars and phosphorus levels affected root weight (g)

\section{Yield per plot $(\mathbf{k g})$}

The statistical analysis of data revealed that different phosphorus levels and cultivars significantly influenced yield per plot $(\mathrm{kg})$ of radish while their interaction (Figure 6) was found non-significant. From the mean Table it is cleared that maximum yield per plot $(3.63 \mathrm{~kg})$ were noted in plants treated with $\mathrm{P}$ at rate of $60 \mathrm{~kg}$ per ha, whereas minimum yield per plot $(2.64 \mathrm{~kg})$ were recorded in control treatment. Among cultivars, Green neck showed maximum yield per plot $(3.49 \mathrm{~kg})$ while the minimum yield per plot $(2.39 \mathrm{~kg})$ was observed in Long red radish. Marked differences in different cultivars of radish might be due to reason for increased yield plant $^{-1}$. The genetic makeup also contributes to the increased yield of radish. Similar trend was observed by [20], who evaluated radish cultivars and found that radish cultivar Japanese White gave maximum yield, longest roots and more number of leaves. Phosphorus is an vital nutrient for growth and development of plants along with other major elements. It plays essential role in metabolism and energy producing functions in foliage plants [7]. Similar results were found by [21], which showed that root yield and growth components were significantly influenced by nitrogen and phosphorus combinations and increased levels of nitrogen and $\mathrm{P}_{2} \mathrm{O}_{5}$ fertilizer combination showed significantly increased growth and yield parameters. 


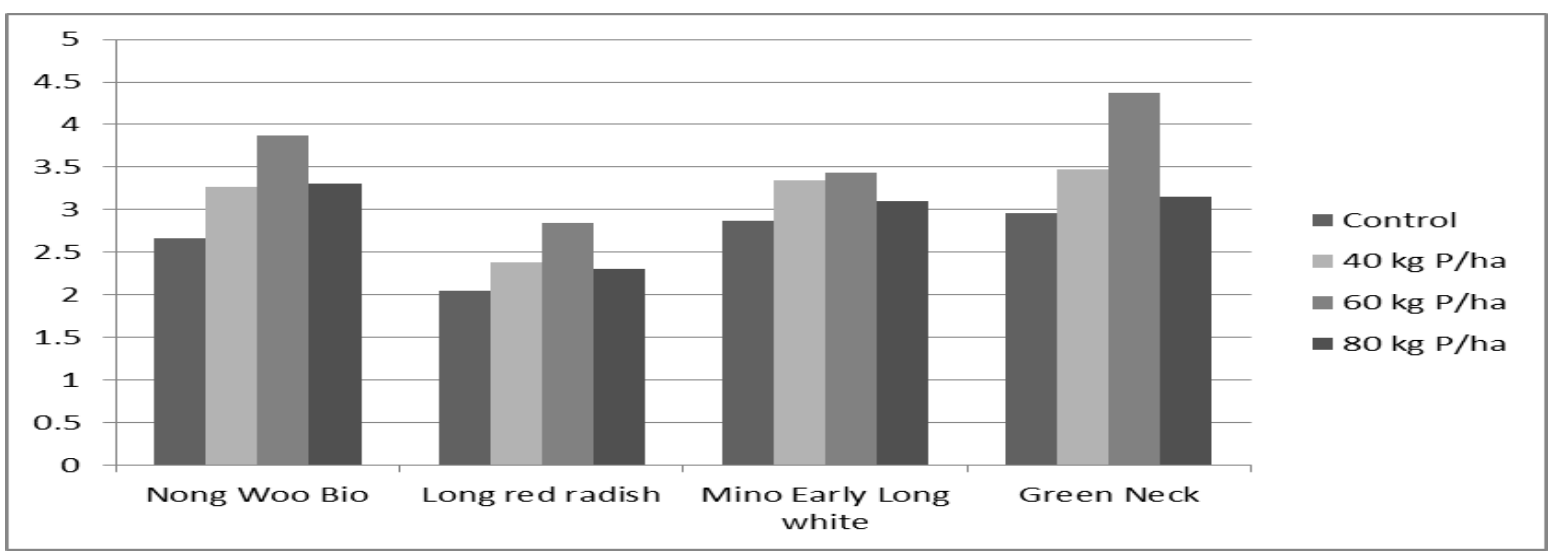

Figure 6. Interaction between radish cultivars and phosphorus levels affected yield per plot (kg)

\section{Total yield (tons ha-1)}

The statistical analysis of data revealed that various phosphorus levels and cultivars significantly influenced yield $\mathrm{ha}^{-1}$ (tons) of radish while their interaction (Figure 7) was found non-significant. From the mean Table it is clear that maximum yield per hectare (29.50tons) were noted in plants treated with $\mathrm{P}$ at rate of $60 \mathrm{~kg}$ per ha, whereas minimum yield per hectare (23.25tons) were recorded in control treatment. There was a significant variation observed in different radish cultivars, in which cultivar Green neck showed maximum yield per hectare (29.88tons) while the minimum yield per hectare (21.30tons) was observed in Long red radish. The reason of marked differences in the yield of radish might be the genetic makeup of the different radish cultivars under trail. The results of Sharma et al. [21] who evaluated radish cultivars and found that radish cultivar Japanese White gave maximum yield, longest roots and more number of leaves. Similarly phosphorous is a constituent of vital molecules such as nucleic acids, phospholipids and ATPs. It is involved in various functions of plants that includes controlling enzyme reactions, regulation of metabolic pathways, energy transfer, photosynthesis and transformation of carbohydrates as well as formation of oils. The addition of nitrogen with phosphorus and potash significantly increased total yield per hectare. Maximum yield was attained from the plots with maximum rates of NPK. By using fertilizer nutrients, radish yield was enhanced so the farmers can increase radish yield by applying increased quantity of $\mathrm{N}$ and $\mathrm{P}$ nutrients [11]. Similar results were obtained by [22] in a study on assessing indicators of advanced yield in production of radish.

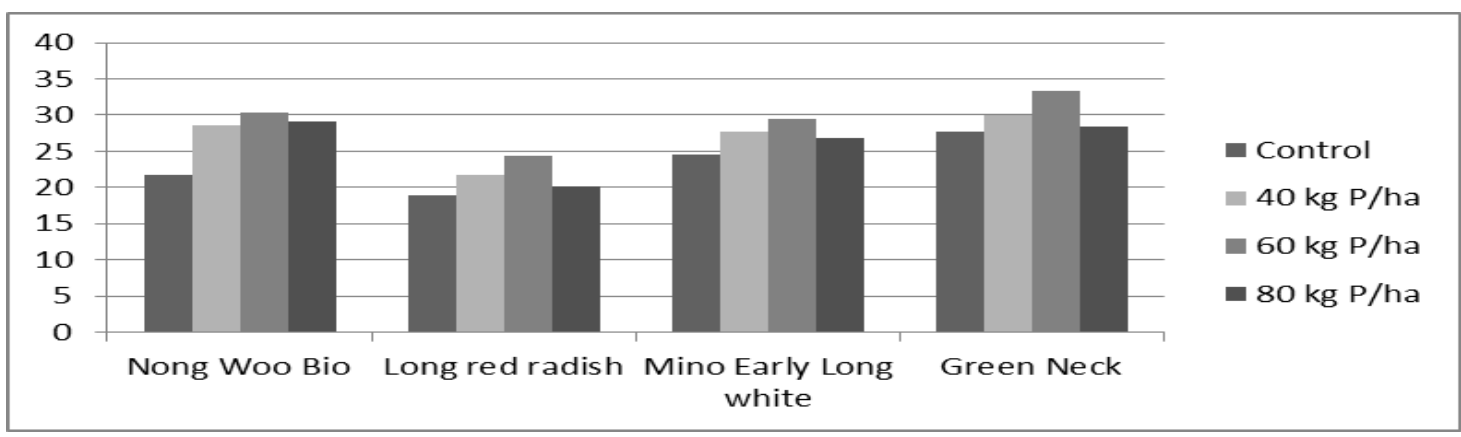

Figure 7. Interaction between radish cultivars and phosphorus levels affected yield ha-1 (tons) 


\section{Conclusions and recommendations}

From the research it is concluded that phosphorus level $60 \mathrm{~kg}$ per ha is effective in escalating the growth and yield components such as number of leaves, root diameter, root length, root weight and yield per hectare, as compared to control treatment. Cultivar Green neck performed better than other cultivars in all growth parameters studied during the course of research work. Hence, $\mathrm{P}$ at rate of $60 \mathrm{~kg} \mathrm{ha}^{-1}$ and Green neck cultivar is recommended for Peshawar growers for better yield and performance.

\section{Authors' contributions}

Design the experiment: $G$ Ayub, Data collection and analysis: R Zeb, Technical help, data analysis and revision of the manuscript: M Ilyas.

\section{References}

1. Baloch AF (1994). Vegetable Crops. Horticulture national Book Foundation. Islamabad 489-537.

2. Anon (2006). Statistics of Pakistan. 20052006. Government of Pakistan, Ninistry of Food, Agriculture and Livestock (Economics Wing), Islamabad.

3. Jilani MS, Burki $\mathrm{T} \&$ Waseem $\mathrm{K}$ (2010). Effect of nitrogen on growth and yield of radish. $J$ Agric Res 48(10).

4. Ahmad F, Ahmad, S Faridullah \& Mehmood, S (2003). Performance of radish cultivas at juglote, northern areas Pakistan. Plant Genetics and Breeding 19(4): 489-491.

5. Wajid A, Ahmad A, Khaliq T, Alam S, Hussain A, Hussain K, Naseem W, Usman M \& Ahmad S (2010). Quantification of growth, yield and radiation use efficiency of promisisng cotton cultivars at varying nitrogen levels. Pak J Bot 42(3): 1703-1711.

6. Daufault RJ (1985). The relationship among nitrogen, phosphorous and potassium fertility regimes on celery transplant growth. Hort Sci 20: 11041106.
7. Djurovka M, Markovie V, Hin Z, Jevie $\mathrm{S} \&$ Lazie B1(997). The effect of nitrogen fertilizer on dry matter contents and minerals elements in radish. Acta Horti 1(462): 139-144.

8. Dudnik SA, Antonov AV \& Pleshkov KK (1981). Effectiveness of fertilization in early cabbage under irrigation. Hort Abst 51(8): 29-30.

9. Shaheen AM, Abdel-Mouty MM, Ali AH \& Rizk FA (2007). Natural and chemical phosphrous fertilizers as affected onion plant growth, bulb yield and its some physical and chemical properties. Aust J Basic Appli Sci 1(4): 519-524.

10. Ali S, Akhtar M \& Iqbal A (2003). Effect of nitrogen and herbicide on growth and yield of wheat. Asian $J$ Plant Sci 2: 1212-1214.

11. Thapa U, Mohanto B, Chattopadhyay S B \& Ghanti P (2003). Growth and yield of some cultivars of radish with nitrogen levels. Environment and Ecology 21(4): 836-838.

12. Joshi PC \& Patil NS (1992). Note on effect of plant density, nitrogen and phosphrous on the yield of radish. Indian J Hort 49(3): 265-266.

13. Baksh K, Ahmad B, Gill Z. A \& Hussain, S (2006). Estimating indicator of higher yield in radish cultivation. Int J Agri Biol 8(6): 783-787.

14. Maynard DN (1962). Influence of nitrogen levels on flowering and fruit set of peppers. Procee. Amer Soc Hort Sci 11: 385-389.

15. Demkin VI \& Ageev VV (1990). Productivity of maize as dependent on weather conditions and fertilizers and methods of coverisng those in a zone of unstable moisture supply. Agrokhimiya 7: 73-82.

16. Dixit SP \& Sharma PK (2004). Effect of lime and phosphorous on yield and 
phosphrous uptake by radish in mountain acidic soil of North-West Hamalayas, India 74(5): 239-241

17. Din M, Qasim M \& Alam M (2005). Effect of different levels of N, P, and K on the growth and yield of cabbage. $J$ Agric Res 45(2): 171-176.

18. Ghanti P, Sounda G, Jana PK \& Som MG (1982). Effect of levels of nitrogen phosphrous and spacing on the yield characteristic of cabbage. Veg Sci 9: 14.

19. Halim GMA \& Ahmad MS (1989).Effect of different levels of NPK on the growth and yield of cabbage. BAAS Dhaka (Bangladesh) 126.
20. Kakar AA, Jamro G H, langov MI \& Shafique $M$ (2001). Effect of $N$ and $P$ on the growth and root yield of radish. Baloch J Agri Sci 2(2): 11.

21. Sharma VK, Chandel KS, Kalia \& Pathania NK (2002). Performance of different cultivars of cultivars of radish tp phosphrous and its impact on radish top and development. Indian J Horti 65(3): 285-288.

22. Wood C, Kingry WL, Delaney DP, Williams JC \& Mullins (1994). Impact of long term land application of broiler litter on environmentally related soil properties. J Envir Qual 23: 139-147. 